\title{
Selective Transport of Lead(II) through a Bulk Liquid Membrane Using a Cooperative Carrier Composed of Benzylaza-12-crown-4 and Oleic Acid
}

\author{
Sayed Yahya Kazemi ${ }^{\dagger}$ and Mojtaba Shamsipur* \\ 'Department of Basic Science, Agriculture College, Mazandaran University, P. O. Box 578, Sari, Iran \\ Department of Chemistry, Razi University,Kermanshah,Iran. "E-mail: mshamsipur@yahoo.com \\ Received December 31, 2004
}

\begin{abstract}
A chloroform membrane system containing a given mixture of benzylaza-12-crown-4 and oleic acid is introduced for the selective and efficient transport of $\mathrm{Pb}^{2+}$ ion. The transport was capable of moving metal ions 'up-hill'. In the presence of $\mathrm{S}_{2} \mathrm{O}_{3}{ }^{2-}$ ion as a suitable metal ion acceptor in the receiving phase, the amount of lead ion transport across the liquid membrane after 150 minutes is $(95.0 \pm 1.7) \%$. The selectivity and efficiency of lead transport from aqueous solution containing $\mathrm{Tl}^{+}, \mathrm{Ag}^{+}, \mathrm{Mg}^{2+}, \mathrm{Ca}^{2+}, \mathrm{Co}^{2+}, \mathrm{Ni}^{2+}, \mathrm{Cu}^{2+}, \mathrm{Zn}^{2+}, \mathrm{Hg}^{2+}$ and $\mathrm{Cd}^{2+}$ were investigated. In the presence of thiosulfate as a suitable masking agent in the source phase, the interfering effects of $\mathrm{Ag}^{+}$and $\mathrm{Cu}^{2+}$ were diminished drastically.
\end{abstract}

Key Words : Liquid membrane, Lead transport, Benzylaza-12-crown-4, Oleic acid, Thiosulfate

\section{Introduction}

Selective removal of $\mathrm{Pb}^{2+}$ for environmental remediation and in the treatment of acute and chromic lead poisoning remains an important objective. ${ }^{1-3}$ Attempts to remove toxic heavy metal ions (e.g., $\mathrm{Cd}^{2+}, \mathrm{Hg}^{2+}$ and $\mathrm{Pb}^{2+}$ ) from the environment and from biological systems have utilized a variety of separation methods such as adsorption, precipitation, solvent extraction and liquid membrane transport. Carrier-mediated transport of metal ions through bulk liquid membranes is not only interesting for its potential as a model for a biological membrane, but also for its potential applications to selective removal, concentration and purification of metal ions from their mixtures. ${ }^{4,5}$

The complexing ability of crown ethers toward soft heavy metal ions is quite low. ${ }^{1,6}$ This problem has been overcome by substitution of some oxygen atoms by sulfur or nitrogen atoms which results in a considerable increase in the stability of cations such as $\mathrm{Ag}^{+}, \mathrm{Tl}^{+}$, and $\mathrm{Hg}^{2+}$ ions in solution, ${ }^{7-9}$ while diminishing the stability constants of their alkali and alkaline earth complexes. ${ }^{1,6}$ A major problem associated with the use of aza-substituted crown ethers as metal ion carriers is their substantial bleeding from the membrane phase into the aqueous phase. It has been shown that the addition of long chain fatty acids to the membrane phase could not only overcome the carrier loss but also provide a cooperative effect in the uphill transport of metal ions through the liquid membrane via imparting a greater lipophilicity to the carrier species. ${ }^{10-13}$

In recent years, we have used some aza- and thiasubstituted macrocyclic compounds as neutral ion carriers in membrane transport, ${ }^{12,13}$ supported liquid membrane transport, ${ }^{14}$ carbon paste ion selective electrodes, ${ }^{15}$ and in PVCmembrane electrode studies of some metal ions. ${ }^{16-18}$

In this investigation, it found that benzylaza-12-crown-4 (BzA12C4) and oleic acid (OA) can act as excellent specific ion carrier for the highly efficient and selective transport of
$\mathrm{Pb}^{2+}$ ion through a bulk chloroform membrane. In the presence of thiosulfate as a suitable metal ion acceptor in the receiving phase, a mixture of $7.0 \times 10^{-4} \mathrm{M}$ of BzA12C4 and $0.04 \mathrm{M}$ of $\mathrm{OA}$ in chloroform phase was found to transport the $\mathrm{Pb}^{2+}$ ion quantitatively and selectively across the liquid membrane at $150 \mathrm{~min}$.

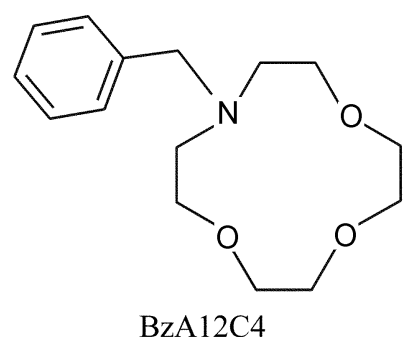

Experimental Section

Reagents and chemicals. Benzylaza-12-crown-4 (BzA12C4), dicyclohexyl-18-crown-6 (DC18C6), dibenzo18-crown-6 (DB18C6), benzo-15-crown-5 (B15C5), aza-18crown-6 (A18C6), dibenzyldiaza-18-crown-6 (DBzDA18C6) and dibenzodiaza-15-crown-4 (DBDA15C4) were purchased from either Fluka or Merck chemical companies and used as received. Extra pure chloroform (Merck) was used as the membrane organic solvent. Analytical grade sodium thiosulfate, lead nitrate, and the nitrate salts of other cations used (all from Merck) were of the highest purity available from and used without further purification except for vacuum drying over $\mathrm{P}_{2} \mathrm{O}_{5}$. Doubly distilled deionized water was used throughout.

Apparatus. A bulk type liquid membrane cell ${ }^{19}$ was used in all experiments (Figure 1). A Varian-10 atomic absorption spectrophotometer (AAS) was used for monitoring the metal content of the aqueous phases, under the recommended conditions for each metal ion.

Procedure. All transport experiments were carried out at 


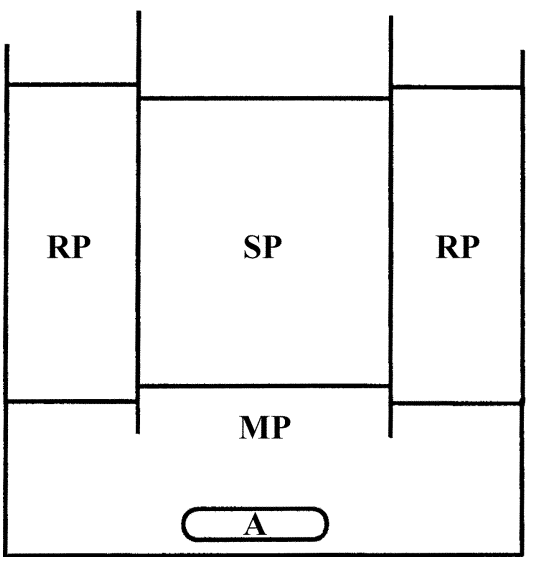

Figure 1. Representation of the bulk type liquid membrane cell used: SP, source phase; RP, receiving phase; MP, membrane phase; A, magnetic stirrer.

ambient temperature. A cylindrical glass cell (inside diameter $4.0 \mathrm{~cm}$ ) holding a glass tube (inside diameter $2.0 \mathrm{~cm}$ ), thus separating the two aqueous phases, was used (Figure 1). The inner aqueous phase (source phase, $\mathrm{SP}, 5 \mathrm{~mL}$ ) contained lead nitrate $\left(1.0 \times 10^{-4} \mathrm{M}\right)$. The outer aqueous phase (receiving phase, RP, $10 \mathrm{~mL}$ ) included sodium thiosulfate $(0.2 \mathrm{M})$. A chloroform phase $(20 \mathrm{~mL})$ containing BzA12C4 $\left(7.0 \times 10^{-4} \mathrm{M}\right)$ and $\mathrm{OA}(0.04 \mathrm{M})$ lay below these aqueous phases, and bridged them. The organic layer was magnetically stirred by a Teflon-coated magnetic bar $(2 \mathrm{~cm} \times 5 \mathrm{~mm}$ diameter) at $150 \mathrm{rpm}$. Samples of both aqueous phases were analyzed for metal content by AAS. A similar transport experiment was carried out in the absence of the cooperative carrier for reference. The detailed conditions are included in the tables of the text.

\section{Results and Discussion}

The liquid membrane used in this study is shown schematically in Figure 2. The $\mathrm{Pb}^{2+}$ ion is transported from the source phase to the receiving phase via a chloroform membrane. The movement of charged species through the hydrophobic liquid membrane is accomplished by the presence of a cooperative host composed of BzA12C4 and OA. After complexation of the carrier with $\mathrm{Pb}^{2+}$ ion on the left side of the membrane, the complex diffuse down its concentration gradient. On the right side of the membrane, the metal ion would be released into the receiving phase via formation of a ternary complex (carrier-metal ion-thiosulfate). At this stage, the free carrier diffuses back across the liquid membrane. The net result is the transport of $\mathrm{Pb}^{2+}$ ion from the aqueous source phase to the aqueous receiving phase across the bulk of organic phase (the membrane).

The preliminary experiments revealed that BzA12C4 alone was not an effective carrier for the efficient transport of lead through the bulk liquid membrane. This is mainly due to the considerable solubilities of the free and complexed forms of the macrocyclic ligand inm aqueous phases. However, as it has been noticed elsewhere, ${ }^{10-13,19}$ the

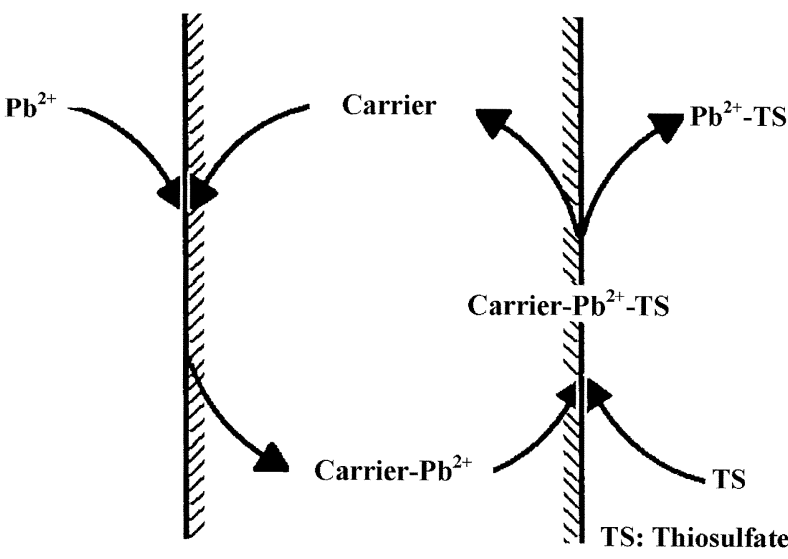

Figure 2. Liquid membrane system for transport of $\mathrm{Pb}^{2+}$ ions.

addition of a long chain fatty acid such as oleic acid not only significantly reduces the degree of carrier loss, but also could have a cooperative effect in the uphill transport of $\mathrm{Pb}^{2+}$ ion through the liquid membrane. A possible reason for this cooperative behavior would be existence of some proton donor-acceptor interaction between the lipophilic fatty acid (as proton donor) and nitrogen atom of the BzA12C4 (as proton acceptor), which can impart a grater degree of lipophilicity to the crown ether-metal ion complex, in order to facilitate the cation transport through the liquid membrane.$^{11}$ Another possibility is that the fatty acid would form an inverse micelle, ${ }^{20-21}$ inside of which the carrier molecule and its lead complex may be trapped. The crown ether may then be easily transported across the membrane inside the inverse micelle formed.

The membrane system was first optimized with respect to the relative concentration of BzA12C4/OA, by keeping the amount of one of the constituents constant and varying the concentration of the other one. The results are summarized in Tables 1 and 2. As seen, while BzA12C4 and OA alone can transport about $18 \%$ and $6 \%$ of lead after $150 \mathrm{~min}$, respectively, a given mixture of them (about $7 \times 10^{-4} \mathrm{M}$ BzA12CA and $4.0 \times 10^{-2} \mathrm{M} \mathrm{OA}$ ) is much more effective in the efficient transport of lead.

Table 1. Effect of BzA12C4 concentration in the membrane phase on $\mathrm{Pb}^{2+}$ ion transport ${ }^{a}$

\begin{tabular}{ccc}
\hline $\begin{array}{c}\text { Ligand } \\
\text { concentration } \\
(\mathrm{M})\end{array}$ & $\begin{array}{c}\text { Percentage } \\
\text { transported } \\
\text { into receiving phase }\end{array}$ & $\begin{array}{c}\text { Percentage } \\
\text { remaining } \\
\text { in source phase }\end{array}$ \\
\hline 0.0 & 6 & 87 \\
$2.0 \times 10^{-4}$ & 40 & 42 \\
$3.5 \times 10^{-4}$ & 71 & 16 \\
$5.0 \times 10^{-4}$ & 86 & 5 \\
$6.0 \times 10^{-4}$ & 90 & 2 \\
$7.0 \times 10^{-4}$ & 95 & 2 \\
$8.0 \times 10^{-4}$ & 96 & 1 \\
\hline
\end{tabular}

${ }^{a}$ Conditions: source phase, $5 \mathrm{~mL}$ of $1.0 \times 10^{-4} \mathrm{M} \mathrm{Pb}^{2+}$; membrane phase, $20 \mathrm{~mL}$ of varying amount of $\mathrm{BzA} 12 \mathrm{C} 4$ and $0.04 \mathrm{M}$ of OA; receiving phase, $10 \mathrm{~mL}$ of $0.2 \mathrm{M}$ sodium thiosulfate; time of transport, $150 \mathrm{~min}$. 
Table 2. Effect of oleic acid concentration in the membrane phase on $\mathrm{Pb}^{2+}$ ion transport ${ }^{a}$

\begin{tabular}{ccc}
\hline $\begin{array}{c}\text { OA concentration } \\
(\mathrm{M})\end{array}$ & $\begin{array}{c}\text { Percentage } \\
\text { transported } \\
\text { into receiving phase }\end{array}$ & $\begin{array}{c}\text { Percentage } \\
\text { remaining } \\
\text { in source phase }\end{array}$ \\
\hline 0.00 & 18 & 81 \\
0.01 & 73 & 25 \\
0.02 & 82 & 18 \\
0.03 & 92 & 8 \\
0.04 & 95 & 1 \\
0.05 & 95 & 1 \\
\hline
\end{tabular}

${ }^{a}$ Conditions: source phase, $5 \mathrm{~mL}$ of $1.0 \times 10^{-4} \mathrm{M} \mathrm{Pb}^{2+}$; membrane phase, $20 \mathrm{~mL}$ of $7.0 \times 10^{-4} \mathrm{M} \mathrm{BzA} 12 \mathrm{C} 4$ and varying amount of $\mathrm{OA}$; receiving phase, $10 \mathrm{~mL}$ of $0.2 \mathrm{M}$ sodium thiosulfate; time of transport, $150 \mathrm{~min}$.

Permeability of the membrane system for $\mathrm{Pb}^{2+}$ ion with respect to different stripping agents in the receiving phase was investigated. As expected, it was found that the nature and composition of the ligand used as the scavenger for the transported metal ion in the receiving phase could have a significant effect on the efficiency and selectivity of lead ion transport. ${ }^{10}$ The use, of $\mathrm{S}_{2} \mathrm{O}_{3}{ }^{-2}$ as stripping ligand in the receiving phase caused a large enhancement in the efficiency and selectivity of $\mathrm{Pb}^{2+}$ ion transport. While, the presence of other receiving agents such as thiourea, citric acid, ammonium acetate, L-cystein and L-serin resulted in a pronounced decrease in the efficiency of lead transport. This is most possibly due to lower stability of $\mathrm{Pb}^{2+}$ ion complexes with these receiving agents, in one hand, and their increased tendency for complexation with interfering ions such as $\mathrm{Ag}^{+}$, $\mathrm{Cu}^{2+}, \mathrm{Ni}^{2+}$ and $\mathrm{Co}^{2+}$, on the other hand. ${ }^{22,23}$ The maximum

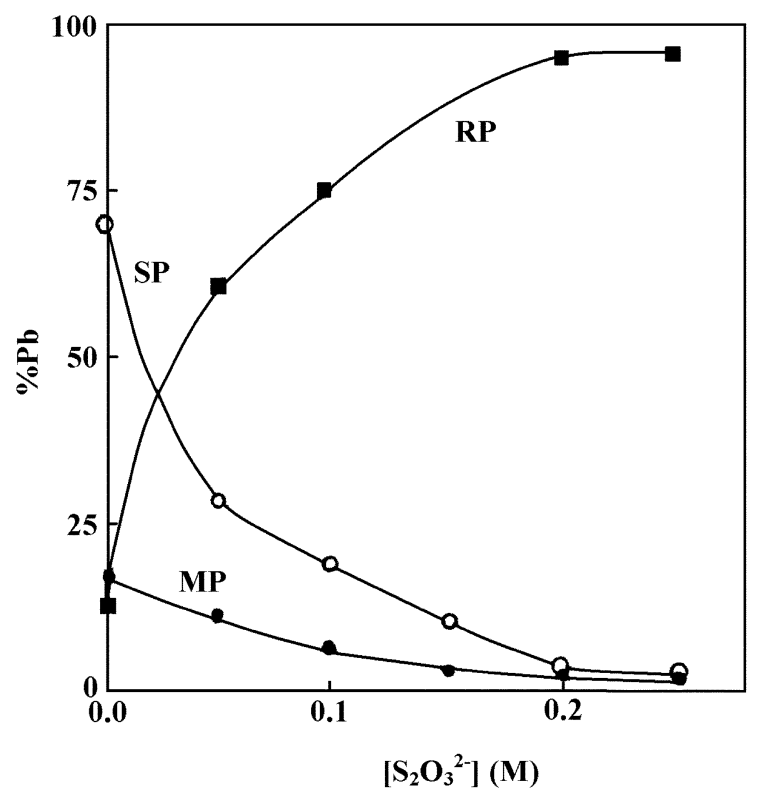

Figure 3. Effect of sodium thiosulfate concentration in receiving phase on lead transport. Conditions: source phase, $5 \mathrm{~mL}$ of $1.0 \times$ $10^{-4} \mathrm{M} \mathrm{Pb}^{2+}$; the membrane phase, $20 \mathrm{~mL}$ of $0.04 \mathrm{M} \mathrm{OA}$ and $7.0 \times$ $10^{-4} \mathrm{M}$ of BzA12C4 in chloroform; receiving phase, $10 \mathrm{~mL}$ of varying amounts of thiosulfate; time of transport, $150 \mathrm{~min}$.
Table 3. Effect of carrier structure on $\mathrm{Pb}^{2+}$ ion transport ${ }^{a}$

\begin{tabular}{lcc}
\hline Carrier & $\begin{array}{c}\text { Percentage } \\
\text { transported } \\
\text { into receiving phase }\end{array}$ & $\begin{array}{c}\text { Percentage } \\
\text { remaining } \\
\text { in source phase }\end{array}$ \\
\hline BzA12C4 & 95 & 2 \\
DBzDA18C6 & 92 & 0 \\
DBDA15C4 & 85 & 8 \\
A18C6 & 65 & 0 \\
DB18C6 & 27 & 60 \\
B15C5 & 11 & 85 \\
DC18C6 & 8 & 85 \\
\hline
\end{tabular}

${ }^{a}$ Conditions: source phase, $5 \mathrm{~mL}$ of $1.0 \times 10^{-4} \mathrm{M} \mathrm{Pb}^{2+} ;$ membrane phase, $20 \mathrm{~mL}$ of $7.0 \times 10^{-4} \mathrm{M}$ ligand and $0.04 \mathrm{M} \mathrm{OA}$; receiving phase, $10 \mathrm{~mL}$ of $0.2 \mathrm{M}$ sodium thiosulfate; time of transport, $150 \mathrm{~min}$.

concentration of sodium thiosulfate in the receiving phase was investigated and results are shown in Figure 3. As seen, maximum lead transport occurs in the presence of 0.15 to $0.25 \mathrm{M}$ thiosulfate in the receiving phase. It is interesting to note that absence of a metal ion acceptor in the receiving phase resulted in no promising lead transport, even at much longer periods of time.

The permeability of the membrane system used for transport of $\mathrm{Pb}^{2+}$ ion was found to be largely dependent on the nature of macrocyclic ligand used in the binary carrier. In other experiments, and under the same experimental conditions, six other crown ethers were used as carrier for transport of lead ion, and the results are given in Table 3. As seen, while in the case of ordinary crown ethers (i.e., DC18C6, B15C5 and DB18C6) the percent lead transport is at the most $27 \%$, the use of aza-substituted crowns (i.e., A18C6, DBzDA18C6, DBDA15C4 and BzA12C4) the lead ion transport efficiency is quite high. This is mainly due to the increased stability of $\mathrm{Pb}^{2+}$ ion as a soft acid with the azasubstituted crown ethers, containing some donating nitrogen as soft bases, over the $\mathrm{Pb}^{2+}$-ordinary crown complexes. ${ }^{1,6,9,24-26}$ Thus, in the case of DC18C6, B15C5 and DB18C6 the transport efficiency is low, mainly due to incomplete extraction of $\mathrm{Pb}^{2+}$ from the source phase into the organic membrane. On the other hand, in the case of A18C6, DBzDA18C6, BzA12C4 and DBDA15C4, the extraction of lead ion into the membrane is almost quantitative, emphasizing the cooperative action of the macrocycles in the presence of OA. However, among, A18C6, DBzDA18C6, DBDA15C4 and BzA12C4 molecules, the rate of release of $\mathrm{Pb}^{2+}$ ion from the membrane into the receiving phase is largest for BzA12C4, most probably because of the higher stability of its complex with $\mathrm{Pb}^{2+}$ in comparison with $\mathrm{A} 18 \mathrm{C} 6-\mathrm{Pb}^{2+}$, DBzDA18C6-Pb ${ }^{2+}$, and DBDA15C4- $\mathrm{Pb}^{2+}$ complexes. ${ }^{1,6}$

Additionally, the concentration-time profile of $\mathrm{Pb}^{2+}$ ion transport through the liquid membrane under optimal experimental conditions was studied. Figure 4 shows that both the extraction of $\mathrm{Pb}^{2+}$ ion from the source phase into the membrane and its release from the membrane into the receiving phase are fast, so that the lead transport occurs 


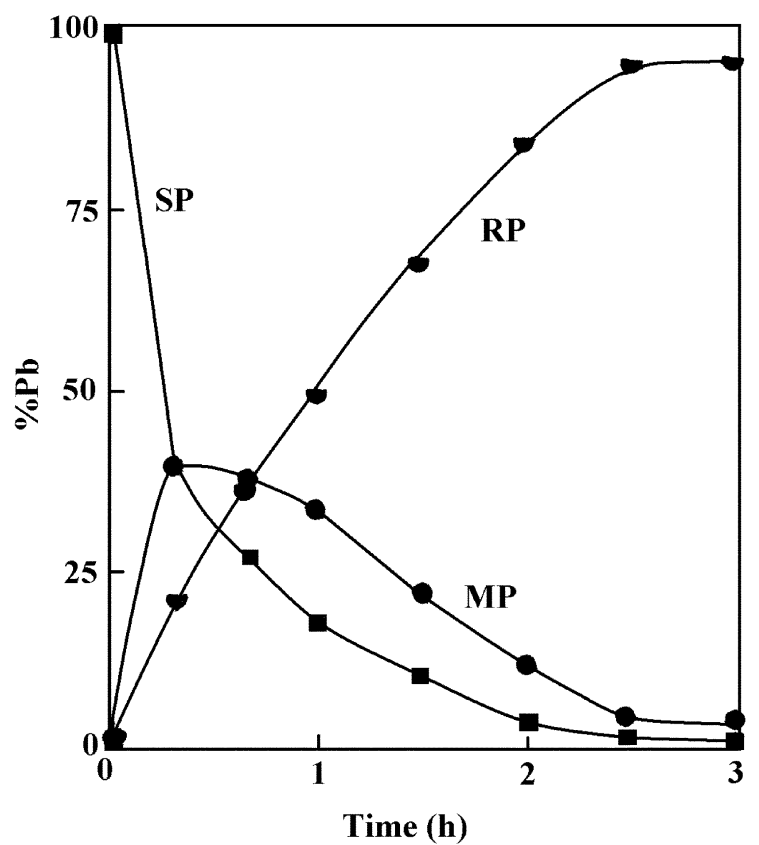

Figure 4. Time dependence of $\mathrm{Pb}^{2+}$ transport. Conditions: source phase, $5 \mathrm{~mL}$ of $1.0 \times 10^{-4} \mathrm{M} \mathrm{Pb}^{2+}$; membrane phase, $20 \mathrm{~mL}$ of 0.04 $\mathrm{M} \mathrm{OA}$ and $7.0 \times 10^{-4} \mathrm{M}$ of BzA12C4 in chloroform; receiving phase, $10 \mathrm{~mL}$ of $2 \mathrm{M}$ of thiosulfate.

Table 4. Amount of cation transported from various cation mixtures through the membrane

\begin{tabular}{|c|c|c|}
\hline Cations & $\begin{array}{l}\text { Percentage transported } \\
\text { into receiving phase }\end{array}$ & $\begin{array}{l}\text { Percentage remaining } \\
\text { in source phase }\end{array}$ \\
\hline \multicolumn{3}{|l|}{ Mixture1 } \\
\hline $\mathrm{Pb}^{2+}$ & 88 & 2 \\
\hline $\mathrm{Ni}^{2+}$ & 7 & 90 \\
\hline $\mathrm{Co}^{2+}$ & 8 & 91 \\
\hline \multicolumn{3}{|c|}{ Mixture 2} \\
\hline $\mathrm{Pb}^{2+}$ & 91 & 3 \\
\hline $\mathrm{Mg}^{2+}$ & 2 & 97 \\
\hline $\mathrm{Zn}^{2+}$ & 4 & 94 \\
\hline \multicolumn{3}{|c|}{ Mixture 3} \\
\hline $\mathrm{Pb}^{2+}$ & 88 & 8 \\
\hline $\mathrm{Cd}^{2+}$ & 2 & 83 \\
\hline $\mathrm{Hg}^{2+}$ & 0 & 85 \\
\hline \multicolumn{3}{|c|}{ Mixture 4} \\
\hline $\mathrm{Pb}^{2+}$ & 81 & 1 \\
\hline $\mathrm{Cu}^{2+}$ & 40 & 24 \\
\hline $\mathrm{Ca}^{2+}$ & 0 & 99 \\
\hline \multicolumn{3}{|c|}{ Mixture 5} \\
\hline $\mathrm{Pb}^{2+}$ & 83 & 3 \\
\hline $\mathrm{Ag}^{+}$ & 14 & 20 \\
\hline $\mathrm{Tl}^{+}$ & 0 & 97 \\
\hline
\end{tabular}

${ }^{a}$ Conditions: source phase, $5 \mathrm{~mL}$ of $5.0 \times 10^{-5} \mathrm{M} \mathrm{Pb}^{2+}$ and other metal ions; membrane phase, $20 \mathrm{~mL}$ of $7.0 \times 10^{-4} \mathrm{M}$ ligand and $0.04 \mathrm{M} \mathrm{OA}$; receiving phase, $10 \mathrm{~mL}$ of $0.2 \mathrm{M}$ sodium, thiosulfate; time of transport, $150 \mathrm{~min}$.

after $150 \mathrm{~min}$ almost quantitatively under the optimal conditions. The reproducibility of $\mathrm{Pb}^{2+}$ ion transport was
Table 5. Amount of cation transported from a cation mixture through membrane in the presence of sodium thiosulfate in source phase as masking agent ${ }^{a}$

\begin{tabular}{lccc}
\hline Cation & $\begin{array}{c}\text { Percentage } \\
\text { transported into } \\
\text { receiving phase }\end{array}$ & $\begin{array}{c}\text { Percentage } \\
\text { remaining in } \\
\text { source phase }\end{array}$ & $\begin{array}{c}\mathrm{S}_{2} \mathrm{O}_{3}{ }^{2-} \\
(\mathrm{M})\end{array}$ \\
\hline Mixture 1 & 92 & 2 & 0 \\
$\mathrm{~Pb}^{2+}$ & 40 & 24 & \\
$\mathrm{Cu}^{2+}$ & 14 & 20 & \\
$\mathrm{Ag}^{+}$ & & & \\
$\mathrm{Mixture} \mathrm{2}_{\mathrm{Pb}^{2+}}$ & 94 & 2 & $2.0 \times 10^{-4}$ \\
$\mathrm{Cu}^{2+}$ & 36 & 43 & \\
$\mathrm{Ag}^{+}$ & 10 & 74 & \\
$\mathrm{Mixture} \mathrm{3}_{\mathrm{Pb}^{2+}}$ & & & \\
$\mathrm{Cu}^{2+}$ & 91 & 6 & $4.0 \times 10^{-4}$ \\
$\mathrm{Ag}^{+}$ & 9 & 62 & \\
\hline
\end{tabular}

${ }^{a}$ Conditions similar to those mentioned in Table 4 except for varying concentrations of sodium thiosulfate in the source phase.

studied and the percent of transport after $150 \mathrm{~min}$ from eight replicate measurements was found to be $(95.0 \pm 1.7) \%$.

The selectivity of the above system for transport of lead over other cations was investigated by examining the percentage transport of $\mathrm{Pb}^{2+}$ and $\mathrm{M}^{\mathrm{n}+}$ cations, which were present with lead ion in equimolar concentrations (Table 4). As illustrated in Table 4, among the different cations tried, $\mathrm{Cu}^{2+}$ and $\mathrm{Ag}^{+}$ions interfere in the transport of lead ion. It is noteworthy that the negligible interfering effect of other cations could be related to different parameters, including improper ionic size, high hydration energy, and especially decreased tendency for binding with thiosulfate ion. ${ }^{22,27}$ The interfering effects of silver and copper ions on the lead transport were, however, significantly decreased by the addition of low concentrations of sodium thiosulfate, as a suitable masking agent, to the source phase. It should be noted that silver and copper ions form complexes with thiosulfate ion which are much more stable than that with lead ion. ${ }^{22}$ The influence of increased concentration of thiosulfate ion on the interfering effect of $\mathrm{Cu}^{2+}$ and $\mathrm{Ag}^{+}$ions are given in Table 5. As it is clear, in the presence of $4.0 \times$ $10^{-4} \mathrm{M}$ of thiosulfate, the interfering effects of these cations have been reduced significantly.

\section{Conclusion}

The quantitative transport of $\mathrm{Pb}^{2+}$ ion through a chloroform-BzA12C4/OA bulk liquid membrane was investigated. The optimum conditions of transport was found as $7.0 \times$ $10^{-4} \mathrm{M} \mathrm{BzA12C} 4$ and $0.04 \mathrm{M}$ OA in the chloroform membrane, $0.2 \mathrm{M} \mathrm{NaSCN}$ in the receiving phase and a transport time period of $150 \mathrm{~min}$. The possible mechanism of transport was discussed. The simplicity, low cost, high efficiency and selectivity and a relatively short time period for $\mathrm{Pb}^{2+}$ ion transport obtained by the liquid membrane 
system demonstrate its potential applicability to selective removal, concentration or purification of lead from its mixtures.

Acknowledgements. The author wishes to express their gratitude to Mazandaran and Razi Universities Research Councils for supporting this work.

\section{References}

1. Izatt, R. M.; Bradshaw, R. S.; Nielsen, S. A.; Lamb, J. D.; Christensen, J. J.; Sen, D. Chem. Rev. 1985, 83, 271.

2. Hancock, R. D. Pure. Appl. Chem. 1986, 58, 1445.

3. Damu, K. V.; Shaikjee, M. S.; Michael, J. P.; Howard, A. S.; Hancock, R. D. Inorg. Chem. 1986, 25, 3879.

4. Noble, R. D.; Way, J. D. Liquid Membrane, ACS Symposium Series 347; American Chemical Society: Washangton, DC, 1987.

5. Liquid Membranes: Chemical Applications; Araki, T.; Tsukube, H., Eds.; CRC Press: Boca Raton, FL, 1990.

6. Izatt, R. M.; Bradshaw, J. S.; Bruening, R. L. Chem. Rev. 1991, 91, 1721

7. Rounaghi, G.; Popov, A. I. J. Inorg. Nucl. Chem. 1981, 43, 911.

8. Frensdorff, H. K. J. Am. Chem. Soc. 1971, 93, 600.

9. Lindoy, L. F. Chem. Soc. Rev. 1975, 4, 421.

10. Lindoy, L. F.; Boldwin, D. S. Pure. Appl. Chem. 1989, 61, 909.

11. Dadfarnia, S.; Shamsipur, M. Bull. Chem. Soc. Jpn. 1992, 65,
2779.

12. Kazemi, S. Y.; Shamsipur, M. Sep. Purif. Technol. 1999, 17, 181.

13. Dadfania, S.; Shamsipur, M. J. Membr. Sci. 1992, 75, 61.

14. Shamsipur, M.; Kazemi, S. Y.; Azimi, G.; Madaeni, S. S.; Lippolis, V.; Garau, A. Isaia, F. J. Member. Sci. 2003, 215, 87.

15. Shamsipur, M.; Khayatiyan, G.; Kazemi, S. Y.; Niknam, K.; Sharghi, H. J. Incl. Phenom. 2001, 40, 303.

16. Shamsipur, M.; Kazemi, S. Y. Electroanalysis 2000, 12, 1472.

17. Shamsipur, M.; Kazemi, S. Y.; Sharghi, H.; Niknam, K. Fresenius J. Anal. Chem. 2001, 371, 1104.

18. Shamsipur, M.; Kazemi, S. Y.; Niknam, K.; Sharghi, H. Bull. Korean Chem. Soc. 2003, 23, 53.

19. Akhond, M.; Shamsipur, M. J. Membr. Sci. 1996, 117, 221.

20. Rosen, M. J. Surfactants and Interfacial Phenomena; John. Wiley: New York, 1978.

21. Myers, D. Surfactant Science and Technology; VCH Publishers: Weinheim, 1988.

22. Laurie, J. Handbook of Analytical Chemistry (English translation); Mir Publisher: Moscow, 1987.

23. Inczedy, J. Analytical Applications of Complex Equilibria; Ellis Horwood: Chichester, 1976.

24. Pearson, R. G. J. Am. Chem. Soc. 1963, 85, 3233.

25. Anderegg, G. Helv. Chim. Acta 1975, 58, 1218

26. Christensen, J. J.; Eatough, D. J.; Izatt, R. M. Chem. Rev. 1974, 74,351 .

27. Eichhorn, G. L. Inorganic Biochemistry; Elsevier: New York, 1973. 